\title{
Germany aims for younger professors
}

[MUNICH] The German University Rectors' Conference (HRK) is proposing to create short-term 'qualification professorships', in an attempt to lower the age at which researchers can become tenured professors, and to offer an alternative to the much criticized Habilitation system.

Possible changes in the federal law are to be discussed by a committee of academic experts set up by research minister Edelgard Bulmahn. The committee will also suggest how academic employment rules could be relaxed, for example, to give universities more freedom to pay professors on performance.

Although Habilitation - or 'equivalent experience' - is required by law for a professorship, many academics consider it an archaic anomaly. US-style assistant professorships do not exist in Germany. Habilitation chains young PhDs to established professors, whom they must serve as 'scientific assistants' to get teaching and research experience. A Habilitand must also submit a thesis, known as an opus magnum.

The procedure, which exists only in German-speaking countries, is criticized for not giving young scientists independent research experience, and for taking too long: the average age at qualification is 40 .

Equivalent experience - such as research, publications and teaching - is now recognized by many science departments, but is difficult to obtain in Germany, where few positions are available for independent research.

Qualification professorships would offer an alternative career path more in tune with international norms, says the report of the HRK's research committee, approved last week by the HRK's plenary council. Young scientists should become eligible to take up a university chair not later than ten years after graduating, it says

The report says that the positions should be advertised openly, to attract those doing PhDs or postdocs abroad. Scientific assistantships leading to Habilitation are too often appointed in-house, contributing to a lack of transparency in promotions and a lack of mobility within the scientific community, says the report.

The qualification professorships should be given to those completing their PhDs at a different university. They should be fouryear appointments, with the possibility of a two-year extension.

Klaus Landfried, president of the HRK, says that the positions would be similar to US assistant professorships, and universities should consider them as part of a tenuretrack system. "Position holders would be responsible for their own teaching and research programmes, and applying for their own research grants," he says.
The idea builds on the new Emmy Noether programme of the research council, the Deutsche Forschungsgemeinschaft (DFG), which supports young scientists for two years of research abroad and a further three years in Germany. These awards are only available to scientists under 30 years of age (see Nature 399, 186; 1999). The HRK and the DFG are "of the same mind" on the need for a career structure for young scientists, says Landfried.

Most scientists have welcomed the proposal, but a few have reservations. Michael Schreiber, professor of theoretical physics at Chemnitz University and a member of the Hochschulverband, the university professors' association, says that Habilitation should be maintained in parallel to the proposed new system because it is the best proof of competence for a professorship.

He also points out that scientists can gain their Habilitation in their mid-thirties, "if they are clever enough to select a research department where Habilitation goes through quickly," such as his own. The HRK's report says that Habilitation should remain an option for those departments with faith in it. But most believe that, given alternative ways of proving competence, Habilitation will slowly fade away.

Bulmahn's committee will present its report on the general relaxation of various legal restrictions on academic employment in
April next year. One member, Hans Meyer, a lawyer who is president of Humboldt University, Berlin, says that there is little resistance to the idea of 'qualification professorships', but more resistance to other ideas, particularly performance-related pay for professors.

The Hochschulverband, for example, fears that decoupling academic appointments from their Beamter (civil servant) status, which would allow universities to vary the pay of professors, would deprive them of the academic freedom that the status guarantees.

Despite this, Meyer predicts that reforms allowing qualification professorships and performance-related pay will be in place by 2002 or 2003, the end of the coalition government's term. Most parliamentarians and state governments are in favour.

But Wolfgang Herrmann, president of the Technical University of Munich, says that universities should not delay action to help young scientists begin independent careers. His university is preparing to convert scientific assistant posts to independent assistant professorships, following amendments to the Bavarian state law on universities this year that give universities more control over their spending. But only a change in the federal framework law on universities would allow these assistant professors to teach their own courses, rather than the courses of an established professor.

Alison Abbott

\section{UK physics postdocs turn to jobs in industry}

[PARIS] Many British physics postdocs are waiting for a permanent faculty position that will never come, concludes a report released last week by the Institute of Physics. The report says that increasing numbers of physicists are heading into industry, notably the booming high-tech sector, banking and computing companies.

The report, Career Paths of Physics Postdoctoral Research Staff, was based on 684 questionnaires from postdocs graduating between 1988 and 1995. It finds that only one in five contract researchers gain permanent university employment, although 61 per cent identify this as one of their goals.

The survey finds that about a third of the respondents are employed in the private sector. Given the choice, half of these now say that they would not repeat their postdoc experience. But, while many postdocs lament not finding a permanent university position, few need to worry about unemployment their unemployment rate is 1.3 per cent.

Philip Diamond, manager of higher education and research at the institute, says the report makes it clear that physicists in $\mathrm{PhD}$ and postdoc positions need more career counselling. "If they're not going to get an

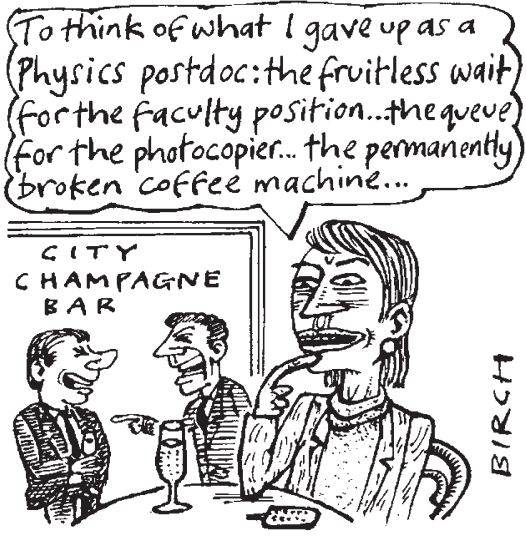

academic post they need to know what is out there," says Diamond. Only one in four postdocs could report any examples of career development in their university.

"The shift in employment indicates an increased willingness on the part of new $\mathrm{PhDs}$ to pursue non-academic employment," says an earlier report from the American Institute of Physics. "The strong economy, coupled with heightened technical sophistication, has [also] increased the number of employers who are seeking the skills a physics doctorate has to offer."

Heather McCabe 